\title{
Samarbeid gir bedre praksisstudier i intensivsykepleie
}

Et prosjekt førte til bedre samarbeid mellom master- og videreutdanningen i intensivsykepleie ved Oslomet og Hjertemedisinsk intensiv og overvåking ved Ullevål sykehus.

\section{Dag-Gunnar Stubberud}

Intensivsykepleier og førstelektor

Institutt for sykepleie og helsefremmende arbeid, Oslomet - storbyuniversitetet

\section{Ingrid Eline Harg}

Intensivsykepleier og praksiskoordinator

Hjertemedisinsk intensiv og overvåking, Oslo universitetssykehus

\section{Pål Solberg}

Intensivsykepleier og fagutviklingssykepleier

Hjertemedisinsk intensiv og overvåking, Oslo universitetssykehus

\section{Anders Adam}

Intensivsykepleier

Hjertemedisinsk intensiv og overvåking, Oslo universitetssykehus

\section{Thorild Ramm}

Intensivsykepleier

Hjertemedisinsk intensiv og overvåking, Oslo universitetssykehus

\begin{tabular}{|l|l|l|}
\hline Veiledning Hjerte- og karsykdom Intensiv Praksisstudier \\
\hline
\end{tabular}




\section{Hovedbudskap}

Kvalitet i studentenes praksisstudier ved master- og videreutdanning $i$ intensivsykepleie krever likeverdig samarbeid mellom utdanningsinstitusjonene og praksisstedene. Samarbeidsprosjekter kan bygge bro mellom praksisfeltet og utdanningsinstitusjonene og bidra til at innholdet i praksisstudiene oppleves som meningsfullt for studentene.

Artikkelen beskriver et samarbeidsprosjekt mellom master- og videreutdanningen i intensivsykepleie ved Oslomet - storbyuniversitetet og Hjertemedisinsk intensiv og overvåking (HIO) ved Oslo universitetssykehus, Ullevål.

Målet med prosjektet var å kvalitetssikre studentenes læringsutbytte i praksisstudiene ved HIO. Praksisveiledningen for studentene har blitt styrket ved å innføre et kompetanseutviklingsprogram for deres praksisstudier.

I henhold til Meld. St. 10 (2012-2013) er kompetanseutvikling en viktig faktor for kvalitet og pasientsikkerhet i helsetjenesten (1). Pasienter med hjertesykdom er en omfattende målgruppe for intensivsykepleiere.

Hjertesykdom er en av de hyppigste dødsårsakene for både kvinner og menn i Norge (2). At studentene får strukturert veiledning i helsehjelp til denne pasientgruppen, kan bidra til $\varnothing \mathrm{kt}$ pasientsikkerhet $(1,3)$.

\section{Bakgrunnen for studien}

Praksisstudiene ved master- og videreutdanningen i intensivsykepleie omfatter 45 studiepoeng, totalt 30 uker (3). Studentene ved Oslomet har praksisstudier ved ulike intensiv- og overvåkningsavdelinger ved flere sykehus i Oslo og Viken. Praksisstudiene fordeles over tre semestre i utdanningen.

Praksisstudier i spesialisthelsetjenesten er en avgjørende kvalifikasjonsarena for å utvikle handlingskompetanse i intensivsykepleie og utøve kunnskapsbasert praksis. Det vil si at helsehjelpen pasienten tilbys, baseres på forskningskunnskap, erfaringskunnskap og pasientkunnskap (4).

\section{«Relevante praksisstudier er viktig for å øke arbeidslivsrelevansen $\mathrm{i}$ høyere utdanning.»}

$\AA$ ut $\varnothing v e$ faglig forsvarlig intensivsykepleie må læres i direkte samhandling med pasienter og pårørende. Bare på den måten kan studentene få erfaringer og utfordringer som er komplekse nok til at læringsutbyttet for utdanningen kan nås. 
I sykepleie til akutt og/eller kritisk syke pasienter må beslutninger ofte fattes raskt. Gjennom praksisstudiene tilegner studentene seg praktisk erfaring slik at de kan utvikle en umiddelbar forståelse av pasientsituasjoner og hvilken kunnskap og handling situasjonen krever. Relevante praksisstudier er viktig for å $\varnothing \mathrm{ke}$ arbeidslivsrelevansen i høyere utdanning $\left(3,5^{-8}\right)$.

\section{HIO er en viktig samarbeidspartner for universitetet}

HIO er en kombinert hjerteintensiv- og overvåkningsavdeling med 13 sengeplasser, hvorav tre er respiratorplasser. Avdelingen behandler akutt og kritisk syke pasienter med hjertesykdom, men også pasienter med andre alvorlige medisinske diagnoser.

HIO har regionansvar for å behandle pasienter med ST-elevasjons hjerteinfarkt (STEMI), pasienter med hjertestans med sannsynlig kardial årsak samt andre kritisk syke hjertepasienter fra store deler av østlandsområdet.

Avdelingen er en viktig samarbeidspartner for universitetets master- og videreutdanning i intensivsykepleie og har til enhver tid tre-fire studenter fra Oslomet. Studentene har fem-sju ukers praksisstudier i avdelingen.

\section{Prosjektet omfattet kompetanseutvikling for praksisstudier}

Prosjektet var et kvalitetsforbedringsarbeid og gikk ut på å utvikle og implementere et kompetanseutviklingsprogram for praksisstudier i hjertemedisinsk intensivsykepleie, som er beskrevet i tabell 1 og figur 1.

Programmet omfattet helsehjelp ved akutte kardiovaskulære tilstander og problemstillinger som er typisk for avdelingen, som akutt koronarsyndrom (AKS), akutt hjertesvikt og hjertearytmier. Prosjektperioden varte fra august 2019 til mars 2021.

AKS er den vanligste tilstanden som behandles i avdelingen, med over 1000 pasienter årlig. Pasienter med AKS utgjør omtrent halvparten av innleggelsene ved HIO, og flesteparten av disse har STEMI. I tillegg behandles mange pasienter med akutt hjertesvikt.

En del av disse har behov for ikke-invasiv overtrykksventilering (CPAP/BiPAP) (150-200 pasienter per år) og mekanisk sirkulasjonsstøtte (aortaballongpumpe og Impella) (30-40 pasienter per år). HIO overvåker også pasienter med hjertearytmier. 
I tillegg til innlagte pasienter ved HIO overvåkes omtrent 3500 pasienter årlig med trådløs hjerterytmeovervåkning (telemetri) fordelt på sju medisinske sengeposter. Avdelingen behandler også hjertestanspasienter som har behov for respiratorbehandling og målrettet temperaturkontroll.

Tabell 1. Kompetanseutviklingsprogram for praksisstudier i hjertemedisinsk intensivsykepleie

\begin{tabular}{|l|l|l|}
\hline Tema & Innhold & Ansvar for gjennomføring \\
\hline $\begin{array}{l}\text { Akutt } \\
\text { koronarsyndrom }\end{array}$ & $\begin{array}{l}\text { E-læringskurs om helsehjelp ved akutt koronarsyndrom } \\
\text { Veiledning i refleksjonsgrupper om intensivsykepleierens } \\
\text { funksjon og ansvar ved helsehjelp til pasienter med STEMI } \\
\text { Én-til-én-veiledning i pasientsituasjoner }\end{array}$ & $\begin{array}{l}\text { Praksisveileder* } \\
\text { og kontaktlærer* } \\
\text { Praksisveileder* }\end{array}$ \\
\hline Akutt hjertesvikt & $\begin{array}{l}\text { E-læringskurs om helsehjelp ved akutt hjertesvikt } \\
\text { Veiledning i refleksjonsgrupper om intensivsykepleierens } \\
\text { funksjon og ansvar ved helsehjelp til pasienter med akutt } \\
\text { Én-til-én-veiledning i pasientsituasjoner }\end{array}$ & $\begin{array}{l}\text { Student } \\
\text { Praksisveileder* }\end{array}$ \\
\hline Hjertearytmier & $\begin{array}{l}\text { Seks timer med undervisning om systematisk } \\
\text { hjerterytmeanalyse } \\
\text { Én-til-én-veiledning i pasientsituasjoner }\end{array}$ & Student og praksisveileder* \\
\hline
\end{tabular}

* Med praksisveileder menes fagpersonen fra praksisstedet som har ansvar for å følge opp studenten som er i praksis.

Med kontaktlærer menes fagpersonen ved utdanningsinstitusjonen som utgjør et bindeledd mellom praksisstedet og utdanningen,

og som bidrar i pedagogiske og faglige spørsmål $(8$, s. 15).

Figur 1. Kompetanseutviklingsprogram

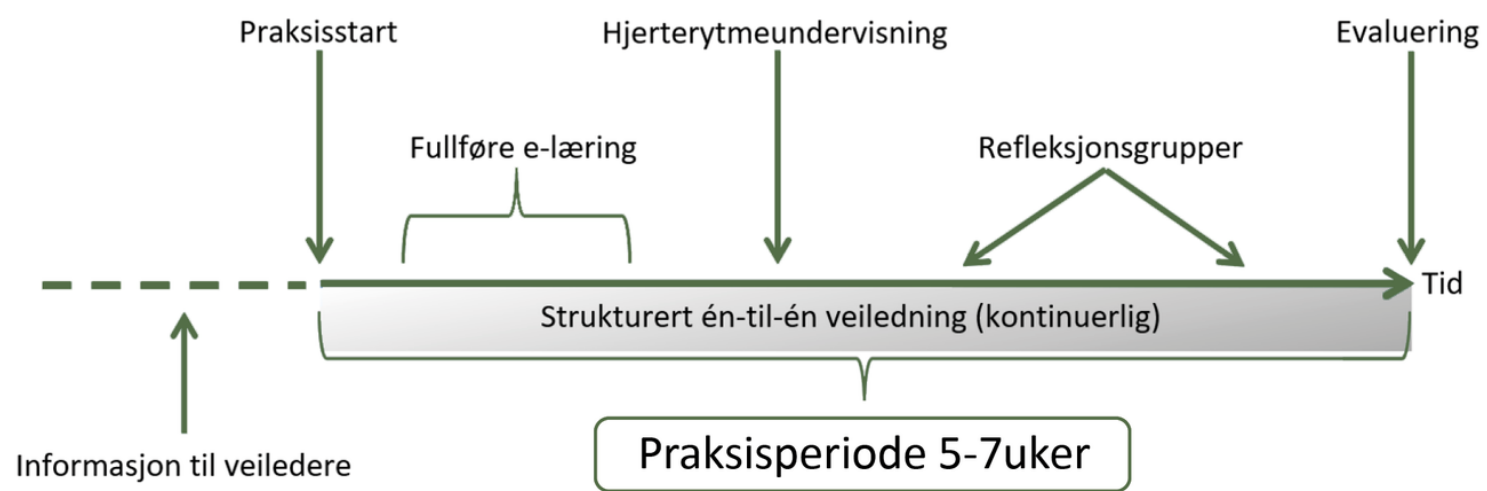

\section{Metode}

På makronivå i arbeidsprosessen fulgte vi Konsmo og medarbeideres (2015) modell for kvalitetsforbedring (se figur 2) (10). Modellen beskriver arbeidsprosessen ved kvalitetsforbedring som en femtrinnsprosess: forberede, planlegge, utføre, evaluere og følge opp.

Modellen er en videreutvikling av Demings sirkel, en mye brukt modell for kvalitetsforbedring. På mikronivå i arbeidsprosessen brukte vi den didaktiske relasjonsmodellen for å utvikle selve programmet (se figur 3). 
Didaktikk kan beskrives som praktisk-teoretisk planlegging, gjennomføring og kritisk analyse av undervisning og læring. Den didaktiske relasjonsmodellen omfatter ulike aspekter det er vanlig å ta hensyn til ved undervisning og veiledning (11).

Figur 2. Modell for kvalitetsforbedring (10)

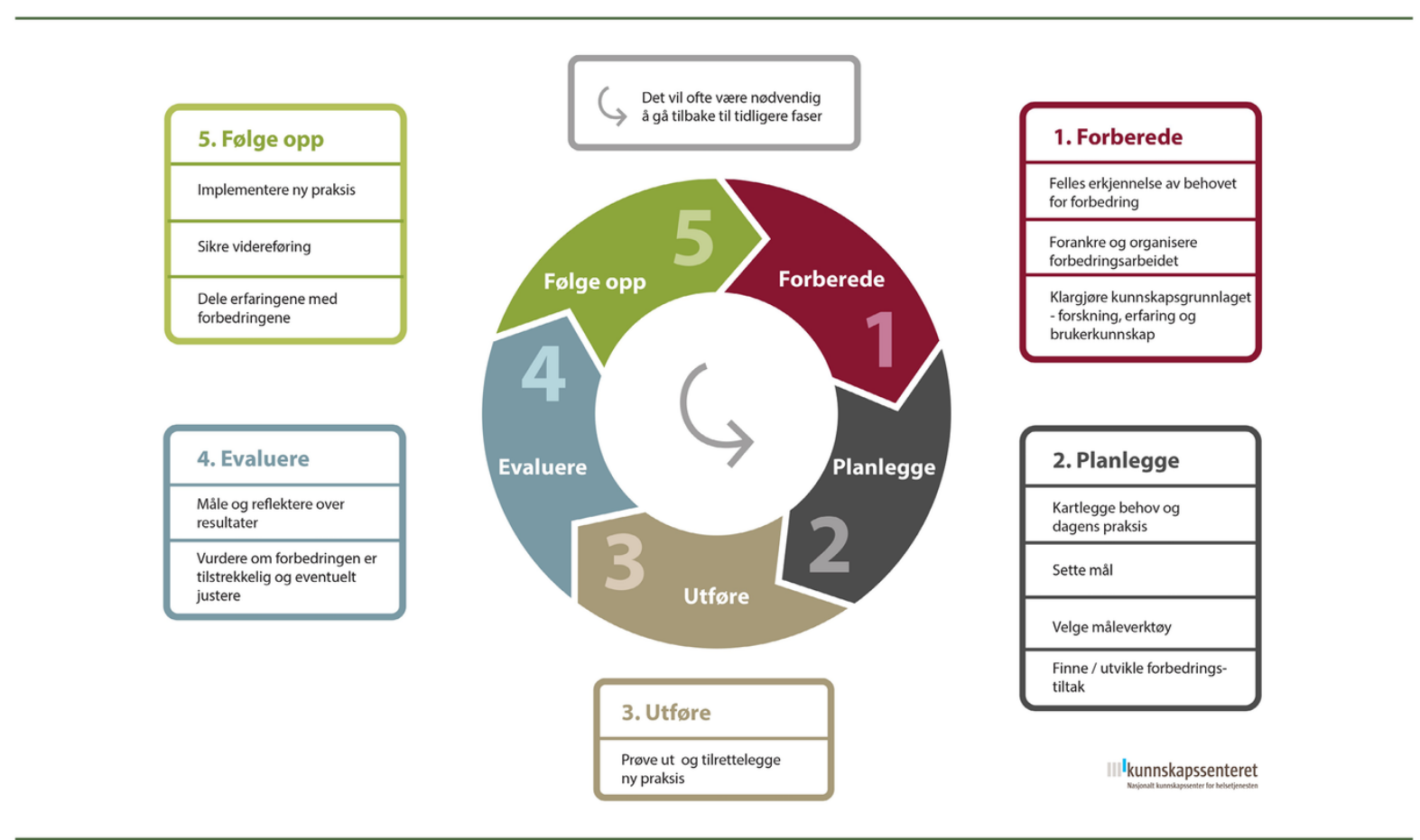

Figur 3. Den didaktiske relasjonsmodellen (11)

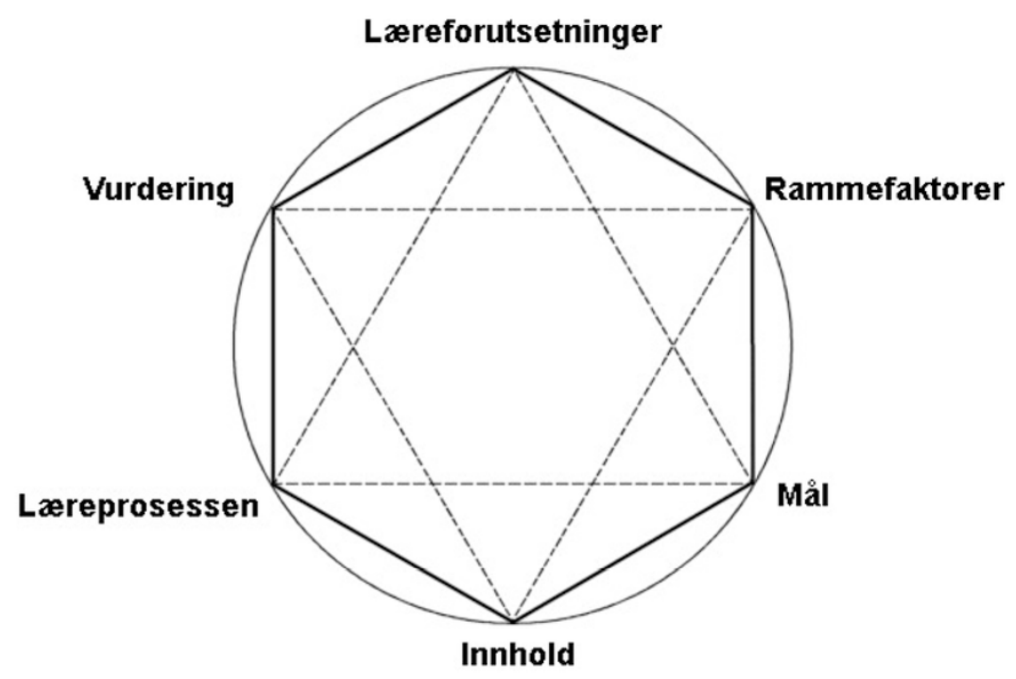

\section{Avdelingen trengte mer struktur i veiledningen}

Avdelingen erkjente et behov for å forbedre praksisveiledningen som studentene fikk tilbud om. Veiledningen var preget av manglende struktur. Praksisstudienes innhold var tilfeldig og i stor grad personavhengig ut ifra hvilke praksisveiledere studentene ble tildelt. 
For å bevisstgjøre studentene om pasientens fysiske og psykiske sårbarhet ved akutt og kritisk hjertesykdom erfarte også utdanningsinstitusjonen at det var behov for mer strukturert innhold i praksisveiledningen.

I samarbeid med master- og videreutdanningen i intensivsykepleie fikk HIO $\varnothing$ konomiske midler fra universitetets samarbeidsmidler. Avdelingen brukte midlene til å frikjøpe prosjektgruppen i ulike stillingsprosenter under prosjektperioden. Prosjektgruppen omfattet tre personer: praksiskoordinatoren ved avdelingen, en fagsykepleier fra avdelingen og en førstelektor fra utdanningen.

\section{Studentene skulle oppfylle læringsutbyttebeskrivelsen}

Målet med prosjektet var å kvalitetssikre at studentene oppfylte læringsutbyttebeskrivelsen for praksisstudiene ved HIO (se tabell 2). Læringsutbyttebeskrivelsen for praksisstudiene ved HIO la grunnlaget for innholdet i programmet (se tabell 1).

\section{«Læringsutbyttebeskrivelsen for praksisstudiene ved HIO la grunnlaget for innholdet i programmet.»}

Med læringsutbytte mener vi det som en person vet, kan og er i stand til å gjøre, som et resultat av en læringsprosess. Læringsutbytte uttrykkes i form av kunnskaper, ferdigheter og generell kompetanse (8, s. 16).

Nivået på læringsutbyttet for både master- og videreutdanningen $\mathrm{i}$ intensivsykepleie er på nivå 7: master (2. syklus), jamfør Nasjonalt kvalifikasjonsrammeverk for livslang læring (NKR). NKR beskriver læringsutbytte for norske utdanninger og hvilket kvalifikasjonsnivå studentene skal ha etter fullført utdanning (12). 
Tabell 2. Utdanningens læringsutbyttebeskrivelse for praksisstudier ved hjertemedisinsk intensiv og overvåking

\begin{tabular}{|c|c|}
\hline Læringsutbytte & Betyr i praksis \\
\hline $\begin{array}{l}\text { Studenten har avansert kunnskap innenfor intensivsyke- } \\
\text { pleierens funksjons- og ansvarsområder. }\end{array}$ & $\begin{array}{l}\text { Studenten kan drøfte intensivsykepleierens funksjons- og } \\
\text { ansvarsområder ved helsehjelp til pasienter med STEMI, } \\
\text { akutt hjertesvikt og hjertearytmier. }\end{array}$ \\
\hline $\begin{array}{l}\text { Studenten har inngående kunnskap om intensivmedisinsk } \\
\text { behandling av akutt og/eller kritisk syke. }\end{array}$ & $\begin{array}{l}\text { Studenten kan drøfte medisinsk behandling ved STEMI, } \\
\text { akutt hjertesvikt og hjertearytmier. }\end{array}$ \\
\hline $\begin{array}{l}\text { Studenten har avansert kunnskap om det å opprettholde } \\
\text { og gjenopprette vitale funksjoner der det er truet. }\end{array}$ & $\begin{array}{l}\text { Studenten kan drøfte intervensjoner for å opprettholde og } \\
\text { gjenopprette vitale funksjoner der det er truet ved STEMI, } \\
\text { akutt hjertesvikt og hjertearytmier. }\end{array}$ \\
\hline $\begin{array}{l}\text { Studenten har inngående kunnskap om pasientens og } \\
\text { pårørendes opplevelser, reaksjoner og behov ved akutt og/ } \\
\text { eller kritisk sykdom i et alders- og flerkulturelt perspektiv. }\end{array}$ & $\begin{array}{l}\text { Studenten kan drøfte pasientens og pårørendes } \\
\text { opplevelser, reaksjoner og behov ved STEMI, akutt } \\
\text { hjertesvikt og hjertearytmier. }\end{array}$ \\
\hline $\begin{array}{l}\text { Studenten kan observere, vurdere og identifisere pasientens } \\
\text { generelle og spesielle behov, ressurser og problemer. }\end{array}$ & $\begin{array}{l}\text { Studenten kan systematisk overvåke pasienter med STEMI, } \\
\text { akutt hjertesvikt og hjertearytmier. }\end{array}$ \\
\hline $\begin{array}{l}\text { Studenten kan opprettholde og gjenopprette vitale } \\
\text { funksjoner der de er truet. }\end{array}$ & $\begin{array}{l}\text { Studenten kan opprettholde og gjenopprette vitale funksjoner } \\
\text { der de er truet ved STEMI, akutt hjertesvikt og hjertearytmier. }\end{array}$ \\
\hline $\begin{array}{l}\text { Studenten kan gjennomføre helt eller delvis kompenserende } \\
\text { intensivsykepleie ved alvorlig svikt i pasientens ressurser for } \\
\text { å ivareta sine grunnleggende behov. }\end{array}$ & $\begin{array}{l}\text { Studenten kan gjennomføre helt eller delvis kompenserende } \\
\text { intensivsykepleie ved STEMI, akutt hjertesvikt og hjerte- } \\
\text { arytmier. }\end{array}$ \\
\hline $\begin{array}{l}\text { Studenten kan forebygge komplikasjoner ved akutt og kritisk } \\
\text { sykdom, avansert medisinsk behandling og intensivsykepleie. }\end{array}$ & $\begin{array}{l}\text { Studenten kan forebygge komplikasjoner ved helsehjelp til } \\
\text { pasienter med STEMI, akutt hjertesvikt og hjertearytmier. }\end{array}$ \\
\hline $\begin{array}{l}\text { Studenten kan analysere og forholde seg kritisk til } \\
\text { eksisterende teori og metoder innenfor avansert medisinsk } \\
\text { behandling og intensivsykepleie. }\end{array}$ & $\begin{array}{l}\text { Studenten kan analysere og forholde seg kritisk til eksister- } \\
\text { ende teori og metoder for helsehjelp ved STEMI, akutt } \\
\text { hjertesvikt og hjertearytmier. }\end{array}$ \\
\hline
\end{tabular}

Etter systematiske kunnskapss $\varnothing \mathrm{k}$ utarbeidet prosjektgruppen

kompetanseutviklingsprogrammet høsten 2019. For å bestemme læreprosessen tok arbeidsgruppen utgangspunkt i det didaktiske redskapet MAKVIS, som står for motivasjon, aktivisering, konkretisering, variasjon, individualisering og samarbeid (14).

MAKVIS kan brukes som overordnede prinsipper ved undervisning og veiledning, men man trenger ikke å følge alle prinsippene slavisk (15).

\section{Studentene fikk også e-læringskurs}

For å skape variasjon i læreprosessen og motivere og aktivisere studentene valgte prosjektgruppen å bruke ulike didaktiske metoder som til sammen kunne bidra til studentenes læring. Én-til-én-veiledning i pasientsituasjoner var den tradisjonelle måten praksisveiledningen ble gjennomført på i avdelingen.

Det vil si at hver student ble tildelt en praksisveileder som veiledet «bedside» i pasientsituasjoner. Denne formen for veiledning ble nå styrket med e-læringskurs, veiledning av studentene i refleksjonsgrupper og en undervisningsdag om systematisk hjerterytmeanalyse. 
Det er ulike meninger om hvilken effekt e-læringskurs har for å utvikle helsepersonells kompetanse (16-18). Prosjektgruppen valgte allikevel å bruke elæringskurs som en av flere didaktiske metoder.

\section{«Det er ulike meninger om hvilken effekt e-læringskurs har for å utvikle helsepersonells kompetanse.»}

Hensikten med e-læringskursene var å konkretisere innholdet ved å gi studentene en rask oversikt over pasientforløpene og behandlingsprinsippene ved AKS og akutt hjertesvikt. Vi ønsket også å dra nytte av andre fordeler med å bruke elæringskurs, som at kursinnholdet er standardisert, slik at studentene får like læringsmuligheter.

E-læringskursene kan også bidra til å aktivisere studentene ved at kursene alltid er tilgjengelige og kan gjennomføres i rolige perioder i avdelingen. I samarbeid med sykehusets kompetanseutviklingsavdeling utviklet prosjektgruppen kursene, som omfattet informasjonsfilmer og tekstsider.

\section{Refleksjonsgrupper var positivt for studentene}

Refleksjon beskrives som et viktig element i praksisstudier (19). Men det er ikke alltid mulig å få tid til refleksjon ved én-til-én-veiledning i pasientsituasjoner. Pasientens fysiske og psykiske tilstand ved akutt og kritisk sykdom kan begrense denne muligheten.

Prosjektgruppen valgte derfor å sette av hele dager til refleksjon med studentene. Refleksjonsgruppene omfattet tre-fire studenter, og praksiskoordinatoren fra avdelingen og kontaktlæreren fra universitetet ledet veiledningen.

Refleksjonsgrupper med få studenter som ledes av en lærer og/eller praksisveileder, synes studentene er positivt. Det kan gi dem arenaer for faglig refleksjon underveis i praksisstudiene. Denne formen for veiledning kan aktivisere studentene og kan også bidra til å knytte teori og praksis sammen $(5,20)$.

At kontaktlæreren er med på å lede veiledningen, bidrar til at vedkommende må holde seg oppdatert i praksisfeltets problemstillinger. Slik oppdatering beskrives som en av kvalitetsindikatorene for å fremme kvalitet i praksisstudiene (8, s. 7).

\section{Veiledningen tok utgangspunkt i pasientcaser}


Veiledningen i refleksjonsgruppene omfattet en systematisk gjennomgang av intensivsykepleierens funksjon og ansvar ved helsehjelp til pasienter med STEMI og akutt hjertesvikt. Veiledningen tok utgangspunkt i reelle pasientcaser og fokuserte på å ivareta ABCDE-prinsippene i helsehjelpen pasienten trenger. Pasientens psykososiale behov ble også vektlagt.

Undervisningen om systematisk hjerterytmeanalyse omfattet å gå igjennom hjertets ledningssystem, forklare hva bølgene i EKG-et representerer, utregne hjertefrekvens, måle de ulike intervallene (PQ, QRS, QT) og vurdere ST-segmentet.

Videre i undervisningen ble de vanligste hjerterytmeforstyrrelsene presentert og forklart av ressurspersoner i avdelingen. Innholdet ble konkretisert ved at det ble vist aktuelle EKG-eksempler underveis i undervisningen. For å aktivisere studentene fikk de utlevert flere EKG-utskrifter som de selv skulle fors $\varnothing$ ke å analysere.

\section{Praksisveilederne må få kunnskap om programmet}

Gjennomføringen av programmet startet 3. februar 2020. I løpet av perioden februar 2020-mars 2021 hadde 14 studenter vært igjennom programmet.

For å kunne støtte studentene i deres læring og utvikling må praksisveiledere kjenne til utdanningens læringsutbyttebeskrivelser, innhold, arbeidsmåter, vurderingsformer og Øvrige rammebetingelser (8, s. 51).

\section{«For å være forberedt skulle studentene arbeide med e- læringsprogrammene før de hadde veiledning $i$ refleksjonsgruppene.»}

I starten av hver praksisperiode fikk derfor praksisveilederne informasjon om hensikten med programmet, programmets innhold og forventet læringsutbytte. Veilederne fikk også utdelt lommekort med råd for én-til-én-veiledningen med studentene.

For å være forberedt skulle studentene arbeide med e-læringsprogrammene før de hadde veiledning i refleksjonsgruppene. Veiledningen i refleksjonsgruppene ble gjennomført to ganger à fem timer i løpet av perioden studentene var i avdelingen.

Det vil si at hver student var med på to gruppeveiledninger: én dag om helsehjelp ved STEMI og én dag om helsehjelp ved akutt hjertesvikt. På grunn av smittevernregler under covid-19-pandemien ble gruppeveiledningen gjennomført digitalt på Microsoft Teams. 


\section{Prosjektet førte til bedre samarbeid}

Kvaliteten i praksisstudier kan som nevnt knyttes til struktur, samarbeid og veiledning. Prosjektet førte til et bedre samarbeid mellom avdelingen og utdanningen. Avdelingen fikk mer kunnskap om utdanningen, og utdanningen fikk mer kunnskap om avdelingen og helsehjelpen pasienten trenger ved akutt og kritisk hjertesykdom.

Tilbakemeldingen fra studenter var at programmet fremmet struktur og forutsigbarhet i veiledningen. De uttalte at programmet bidro til

- å gjøre praksisstudiene i avdelingen meningsfulle

- at de i større grad så helheten i pasientsituasjonen ved STEMI og akutt hjertesvikt

- at de fikk økt handlingsberedskap og -kompetanse, og i større grad var forberedt i ulike pasientsituasjoner

Vi erfarte at aktiviteten fra studentene og samarbeidet mellom dem varierte $\mathrm{i}$ veiledningen. Det var lett for studentene å «gjemme» seg bak en svart skjerm. Den sosiokulturelle læringsprosessen der studentene deltar og bidrar i et læringsfellesskap med medstudenter, ble derfor muligens redusert.

\section{Kvalitetsforbedringsarbeid må endre praksis}

Hensikten med kvalitetsforbedringsarbeid er å endre praksis og skape vedvarende forbedringer $(10,21)$. Det vil si at forbedringen ikke lenger oppleves som en ekstra arbeidsprosess, men er en integrert og fast del av virksomheten (22).

Programmet vil derfor fortsette ut over prosjektperioden. HIO ønsker også å utvikle programmet med innhold om etterbehandling ved hjertestans. Personer som har hatt hjertestans, utgjør den største andelen av avdelingens pasienter som trenger respiratorbehandling. HIO har derfor spesiell kompetanse på denne behandlingsmetoden.

\section{Referanser}

1. Meld. St. 10 (2012-2013). God kvalitet - trygge tjenester: kvalitet og pasientsikkerhet i helse- og omsorgstjenesten. Oslo: Helse- og omsorgsdepartementet; 2012.

2. Folkehelseinstituttet (FHI). Helsetilstanden i Norge 2018. Folkehelserapporten - kortversjon. Oslo: FHI; 2018.

3. Kunnskapsdepartementet. Forskrift om nasjonal rammeplan for videreutdanning i intensivsykepleie. Oslo: Kunnskapsdepartementet; 2005. 
4. Meld. St. 13 (2011-2012). Utdanning for velferd. Samspill i praksis. Oslo: Kunnskapsdepartementet; 2013.

5. Billett S, Cain, M, Le AH. Augmenting higher education students' work experiences: preferred purposes and processes. Studies in Higher Education, 2018;43(7):1279-94.

6. Fetcher E, Kantardjiev K, Skeidsvoll KJ. Hva sier forskning, rapporter og evalueringer om kvalitet i praksis? Del av prosjektet Operasjon praksis 2018-202O. Oslo: NOKUT; 2019.

7. Meld. St. 16 (2016-2017). Kultur for kvalitet i høyere utdanning. Oslo: Kunnskapsdepartementet; 2016.

8. Universitets- og høgskolerådet (UHR). Kvalitet i praksisstudiene i helse- og sosialfaglig høyere utdanning: praksisprosjektet. Oslo: UHR; 2016.

9. Oslo universitetssykehus (OUS). Hjertemedisinsk intensiv og overvåkning. Kompetanseutviklingsmodell i hjertemedisinsk intensivsykepleie. Oslo: OUS; 2021. Tilgjengelig fra: https://ehandboken.ous-hf.no/document/136320 (hentet 08.12.2021).

10. Konsmo T, de Vibe M, Bakke T, Udness E, Eggesvik S, Norheim G, et al. Modell for kvalitetsforbedring: utvikling og bruk av modellen i praktisk forbedringsarbeid. Oslo: Nasjonalt kunnskapssenter for helsetjenesten; 2015.

11. Hiim H, Hippe E. Praksisveiledning i lærerutdanningen: en didaktisk veiledningsstrategi. 2. utg. Oslo: Gyldendal Akademisk; 2006.

12. Kunnskapsdepartementet. Nasjonalt kvalifikasjonsrammeverk for livslang læring (NKR). Oslo: Kunnskapsdepartementet; 2011.

13. Oslomet. Videreutdanning i intensivsykepleie. Programplan. Oslo: Oslomet; 2018. Tilgjengelig fra:

https://student.oslomet.no/studier/-/studieinfo/programplan/VUINTEN/2018/HØS $\underline{\mathrm{T}}$ (nedlastet 08.12.2021).

14. Sylte AL. Profesjonspedagogikk: profesjonsretting/yrkesretting av pedagogikk og didaktikk. Oslo: Gyldendal Akademisk; 2013.

15. Lyngsnes K, Rismark M. Didaktisk arbeid. 4. utg. Oslo: Gyldendal Akademisk; 2020. 
16. Vaona A, Banzi R, Kwag KH, Rigon G, Cereda D, Pecoraro V, et al. E-learning for health professionals. Cochrane Database Syst Rev. 2018;1(1):CDo11736.

17. Voutilainen A, Saaranen T, Sormunen M. Conventional vs. e-learning in nursing education: a systematic review and meta-analysis. Nurse Educ Today. 2017;50:97-103.

18. Warriner DR, Bayley M, Shi Y, Lawford PV, Narracott A, Fenner J. Computer model for the cardiovascular system: development of an e-learning tool for teaching medical students. BMC Medical Education. 2017;17:220.

19. Kantardjiev K, Wiggen KS, Kristiansen E. Praksis sett fra studieprogramleders perspektiv. Del av prosjektet Operasjon praksis 2018-2020. Oslo: NOKUT; 2019.

20. Helseth IA, Fetscher E, Wiggen KS. Praksis i høyere utdanning - gode eksempler. Del av prosjektet Operasjon praksis 2018-2020. Oslo: NOKUT; 2019.

21. Maher L, Gustafson D, Evans A. Guide til implementering og fastholdelse af ny praksis. 4. utg. Århus: Defactum; 2016. Tilgjengelig fra: https://www.defactum.dk/ (nedlastet 01.11.2021).

22. Stubberud D-G. Kvalitet og pasientsikkerhet. Sykepleierens funksjon og ansvar for kvalitetsarbeid. Oslo: Gyldendal Akademisk; 2018. 